UDC 378.147:159.9.018

DOI: 10.31470/2415-3729-2019-10-207-221

\title{
Psychological and Pedagogical Analysis of the Professional Teacher's Career Phenomenon
}

\section{Taras Olefirenko,}

Candidate of Pedagogical Sciences, Associate Professor

Professor of the Department of Theory and Methods of Technology Education

Drawing and Computer Graphics, National Pedagogical Dragomanov University

$\triangle 9$, Pyrohova Str., Kyiv, Ukraine, 01601

E-mail: olephirenko@gmail.com

ORCID: 0000-0002-3278-8125

Date of receipt of the article: October 01, 2019 Article accepted for publication: December 02, 2019

\section{Психолого-педагогічний аналіз феномену професійної кар'сри вчителя}

\section{Тарас Олексійович Олефіренко,}

кандидат педагогічних наук, доцент

професор кафедри теорії і методики технологічної освіти, креслення та комп'ютерної графіки

Національний педагогічний університет імені М.П. Драгоманова $\gtrsim$ вул. Пирогова, 9, м. Київ, Україна, 01601

Дата надходження статті: 01 жовтня 2019 р. Стаття прийнята до друку: 02 грудня 2019 р.

\section{Abstract}

The article proves that knowledge of psychological and pedagogical bases of a professional career phenomenon allows 
to take into account the ascending and descending phases of development, critical periods of life, as well as to predict the influence of socio-economic and personal factors on the teacher's personality development. The purpose of the article is to conduct a psychological and pedagogical analysis of the phenomenon of a professional teacher's career in Ukraine. Consequently the study theoretically grounds the necessity to take into account the modern teacher work peculiarities, due to the specificity of the environment, the presence of constant contacts with people with different temperaments, the need to withstand emotional stability. Moreover the article also confirms that there are a number of issues regarding both the professional development of the teacher's personality and his / her career management. The author of the article notes that this state of affairs is caused by the lack of purposeful influence on the process of the teachers' professional career formation and development, which in turn leads to a decrease in the efficiency of using the educational institution resources. It is important to take into account the main tasks that a teacher performs within the educational process, namely to provide a clear structure of the educational process; to teach students with enthusiasm and passion; to have a positive mood; to use humour during the classes; to increase the interest of students in the lessons; interest in the life of students outside the educational establishment; treat students with respect. As a result the research proves the necessity to take into account psychological and pedagogical components while building a teacher's professional career, they are the level of motivation of professional activity; the ability to empathize; the level of aggression; the level of neuro-psychic stability; the level of emotional burnout; a professional and general erudition; a culture of behaviour; a range of interests; a style of communication; an observance of rights and responsibilities, etc.

Key words: teacher's career, professional career, psychological training, pedagogical training, a student. 


\section{References}

1. Aleksentseva-Timchenko, K.S. (2007). Sotsialni umovy formuvannia uspishnoi kariery [Social conditions for forming a successful career]. Candidate's thesis. Odesa: Odeskyi nats. un-t im. I.I. Mechnykova. In-t sotsialnykh nauk [in Ukrainian].

2. Alshevska, N.Yu. (2000). Trudova kariera pratsivnykiv bankivskoi systemy $\mathrm{v}$ period rynkovykh peretvoren [Labour career of banking system employees' during a period of market transformation]. Candidate's thesis. Kyiv: NAN Ukrainy; In-t sotsiolohii [in Ukrainian].

3. Bila-Tiunova, L.R. (2012). Sluzhbova kariera derzhavnoho sluzhbovtsia: teoriia ta pravove rehuliuvannia [The career of a state worker: theory and legal regulation]. Doctor's thesis. Odesa: Nats. un-t «Odeska yuryd. akad.» [in Ukrainian].

4. Vizirov, B.Y. (2009). Kariera derzhavnoho sluzhbovtsia v Ukraini: teoretychni zasady [The career of a state worker in Ukraine: theoretical background]. Candidate's thesis. Kyiv: Nats. un-t bioresursiv i pryrodokorystuvannia Ukrainy [in Ukrainian].

5. Vintoniak, V.F. (2014). Profesiinyi «Ia-obraz» yak chynnyk vyznachennia ofitserom stratehii kariernoho zrostannia [Professional self-image as a factor in determining the officer's career strategy]. Candidate's thesis. Kyiv: Kyiv. nats. torh.-ekon. un-t [in Ukrainian].

6. Heilyk, A.V. (2013). Orhanizatsiino-pedahohichni umovy profesiinoho zrostannia maibutnikh fakhivtsiv $z$ ekonomiky i pidpryiemnytstva u protsesi navchalno-praktychnoi diialnosti [Organizational and pedagogical conditions of professional growth of future specialists in economics and entrepreneurship in the process of educational and practical activity]. Candidate's thesis. Kyiv: Nats. akad. ped. nauk Ukrainy, In-t vyshch. osvity [in Ukrainian].

7. Zhuravel, A.V. (2014). Interviziia yak zasib pidhotovky maibutnikh psykholohiv do pobudovy profesiinoi kariery [Interviewing as a way to prepare future psychologists to build a professional career]. Candidate's thesis. Kyiv: Kyiv. nats. torh. ekon. un-t [in Ukrainian]. 
8. Kanivets, T.M. (2013). Formuvannia psykholohichnoi hotovnosti studentiv do zdiisnennia maibutnoi profesiinoi kariery [Formation of students' psychological readiness for a future professional career]. Candidate's thesis. Kyiv: Nats. akad. ped. nauk Ukrainy, In-t psykholohii im. H.S. Kostiuka [in Ukrainian].

9. Krymska, O.M. (2012). Pravovi zasady ta formy zabezpechennia profesiinoho zrostannia pratsivnyka $\mathrm{v}$ novykh umovakh ekonomichnoho rozvytku [Legal principles and forms of ensuring the employee's professional growth in the new economic development conditions]. Candidate's thesis. Luhansk: Skhidnoukr. nats. un-t im. Volodymyra Dalia [in Ukrainian].

10. Lytvyniuk, L.V. (2007). Pedahohichne stymuliuvannia profesiinoho zrostannia vchyteliv zahalnoosvitnikh navchalnykh zakladiv [Pedagogical stimulation of a teacher's professional growth of general educational establishments]. Candidate's thesis. Kirovohrad: Kirovohrad. derzh. ped. un-t im. V. Vynnychenka [in Ukrainian].

11. Meshko, H.M. (2010). Vstup do pedahohichnoi profesii [Introduction to a pedagogical profession]. Kyiv : Akademvydav [in Ukrainian].

12. Oksamytna, S.M. (1995). Strukturni ta osobystnisni peredumovy zdiisnennia trudovoi kariery [Structural and personal prerequisites for the realization of a working career]. Candidate's thesis. Kyiv: NAN Ukrainy [in Ukrainian].

13. Poliakov, A.O. (2008). Pedahohichni umovy motyvatsii profesiinoho zrostannia studentiv pedahohichnykh universytetiv $\mathrm{u}$ protsesi neperervnoi osvity [Pedagogical Conditions of Students' Professional Growth Motivation in Pedagogical Universities in the Process of Continuous Education]. Candidate's thesis. Kharkiv: Kharkiv. nats. ped. un-t im. H.S. Skovorody [in Ukrainian].

14. Pryhodii, M.A. (2011). Suchasni aspekty pidhotovky vchyteliv tekhnolohii [Modern aspects of technology teacher training]. Chernihiv: ChNPU imeni T.H. Shevchenka. [in Ukrainian]. 15. Starodubtsev, A.A. (2012). Sluzhbova kariera v orhanakh 
vnutrishnikh sprav Ukrainy: administratyvno-pravovi zasady [Career in the internal affairs agencies of Ukraine: administrative and legal basis]. Doctor's thesis. Kharkiv: Khark. nats. un-t vnutr. sprav [in Ukrainian].

16. Khanenko, I.I. (2012). Sotsialno-psykholohichni osoblyvosti profesiinoho zrostannia zhinok-kerivnykiv u pravookhoronnykh orhanakh Ukrainy [Socio-psychological features of professional growth of female executives in law enforcement agencies of Ukraine]. Candidate's thesis. Luhansk: Skhidnoukr. nats. un-t im. Volodymyra Dalia [in Ukrainian].

17. Shelenkova, N.L. (2014). Rozvytok u maibutnikh psykholohiv psykholohichnoi hotovnosti do zdiisnennia profesiinoi kariery [The development of the future psychologists' psychological readiness for the implementation of professional career]. Candidate's thesis. Kyiv: VNZ «Un-t ekonomiky ta prava «Krok» [in Ukrainian].

18. Meador, D.(2019). Strategies for Teachers to DevelopPositive Relationships with Students. Retrieved from https:/www.thoughtco. com/develop-positive-relationships-with-students-3194339.

\section{Вступ}

В умовах реформування, загальної, професійної (професійно-технічної) та вищої освіти України проблеми професійного розвитку вчителя/викладача набувають особливого значення. Ефективне професійне становлення особистості вчителя відбувається за умов наявності внутрішньої мотивації та систематичного стимулювання на формування професійної компетентності, усвідомленої чіткої програми розвитку професійної кар'єри вчителя та наявності такої програми у адміністрації закладу освіти.

При цьому важливість і комплексний характер проблематики побудови професійної кар'єри вчителя підтверджуються не тільки обставинами особистісного зростання, а й підвищеним інтересом керівників закладів освіти до проблематики розвитку людського капіталу. 
Сучасні дослідники i теоретики прагнуть розглядати кар’єрне зростання в контексті змін, які зачіпають і вчителів, i заклад освіти, і соціум, в межах якого діє заклад освіти.

Разом з тим на практиці фіксується ряд проблем, пов'язаних як із професійним розвитком особистості вчителя, так і 3 управлінням його кар'єрою. Це обумовлено тим, що на стадії вступу до закладу вищої освіти абітурієнти несвідомо підходять до вибору виду майбутньої професійної діяльності, більшість вчителів слабо займаються власним професійним розвитком, недостатньо звертають увагу на перспективи свого кар'єрного розвитку, а також управління кар'єрою в рамках управління персоналом закладу освіти проходить безсистемно, не має наукового обгрунтування.

Відсутність цілеспрямованого впливу на процес формування та розвитку професійної кар'єри вчителів призводить до зниження ефективності використання ресурсів закладу освіти. Оскільки, найвищі досягнення в певному соціально значимому виді професійної діяльності є результатом взаємодії високого професіоналізму і творчої майстерності особистості.

Вивчення психолого-педагогічних основ феномену професійної кар'єри дозволяє врахувати висхідні і низхідні фази розвитку, критичні періоди життя, а також вплив соціальноекономічних та особистісних факторів на розвиток особистості вчителя.

Основу феномену професійної кар'єри вчителя складають Закони України «Про освіту», «Про вищу освіту» та «Про наукову і науково-технічну діяльність».

Різноманітні психолого-педагогічні аспекти розвитку професійної кар'єри фахівців розкриті в дослідженнях вітчизняних вчених: К.С. Алексенцева-Тімченко - соціальні умови формування успішної кар'єри (Алексенцева-Тімченко, 2007); Н.Ю. Альшевська - трудова кар'єра працівників банківської системи в період ринкових перетворень (Альшевська, 2000); Л.Р. Біла-Тіунова - службова кар'єра держав- 
ного службовця (Біла-Тіунова, 2012); Б.Й. Візіров - кар'єра державного службовця в Україні (Вінтоняк, 2014); В.Ф. Вінтоняк - професійний «Я-образ» як чинник визначення офіцером стратегії кар'єрного зростання (Вінтоняк, 2014); А.В. Гейлик - організаційно-педагогічні умови професійного зростання майбутніх фахівців 3 економіки і підприємництва у процесі навчально-практичної діяльності (Гейлик, 2013); А.В. Журавель - інтервізія як засіб підготовки майбутніх психологів до побудови професійної кар'єри (Журавель, 2014); Т.М. Канівець - формування психологічної готовності студентів до здійснення майбутньої професійної кар'єри (Канівець, 2013); О.М. Кримська - правові засади та форми забезпечення професійного зростання працівника в нових умовах економічного розвитку (Кримська, 2012); С.М. Оксамитна - структурні та особистнісні передумови здійснення трудової кар'єри (Кримська, 2012); А.А. Стародубцев - службова кар'єра в органах внутрішніх справ України (Стародубцев, 2012); I.І. Ханенко - соціально-психологічні особливості професійного зростання жінок-керівників у правоохоронних органах України (Ханенко, 2012); Н.Л. Шеленкова - розвиток у майбутніх психологів психологічної готовності до здійснення професійної кар'єри (Шеленкова, 2014).

Разом 3 тим грунтовні дослідження щодо проблематики побудови професійної кар'єри вчителя є малочисельними (Л.В. Литвинюк - педагогічне стимулювання професійного зростання вчителів загальноосвітніх навчальних закладів (Литвинюк, 2007); А.О. Поляков - педагогічні умови мотивації професійного зростання студентів педагогічних університетів у процесі неперервної освіти (Поляков, 2008); М.А. Пригодій сучасні аспекти підготовки вчителів технологій (Пригодій, 2011) та частково не враховують сучасні соціально-економічні аспекти функціонування системи освіти.

Мета статті - провести психолого-педагогічний аналіз феномену професійної кар'єри вчителя в Україні. 


\section{Матеріал і методи дослідження}

Для досягнення поставленої мети використовувалися такі загальнонаукові методи: метод вивчення наукових джерел; аналіз, синтез, порівняння та узагальнення.

\section{Результати та їх обговорення}

Специфікатрудовоїдіяльності сучасноговчителя обумовлюється специфікою середовища, наявністю постійних контактів 3 людьми, які мають різноманітні темпераменти, необхідністю витримувати емоційну стійкість. Професія вчителя пов'язана з постійним напруженням, що створює передумови для постійного розвитку та вдосконалення в межах обраної професії.

За твердженням Г.М. Мешко професійна кар'єра - це послідовність професійних ролей, статусів і видів діяльності в житті людини, iї просування ступенями (щаблями) виробничої, соціальної, адміністративної чи іншої ієрархії (Мешко, 2010).

Для визначення аспектів розвитку професійної кар'єри вчителя проведемо аналіз ролей, статусів і видів діяльності які він повинен виконувати.

Д. Мідор досліджуючи сучасні стратегії з розвитку позитивних відносин учителів з учнями виокремив основні з них (Meador, 2019):

- забезпечте читку структуру освітнього процесу;

- навчайте з ентузіазмом і пристрастю;

- майте позитивний настрій;

- включить гумор у заняття;

- зробити навчання захоплюючим;

- використовуйте інтереси учнів в своїх інтересах;

- включення розповідей історії в хід заняття;

- проявляйте інтерес до життя учнів за межами навчального закладу;

- ставтеся до ним 3 повагою;

- не обмежуйтеся тільки вимогою програми.

Отже, можна зазначити, що передумовами вдалоїпрофесійної кар'єри вчителя виступають прості стратегії яких слід дотримуватись кожного дня. 
Важливо, щоб вчитель визначав особливості навчання учнів заздалегідь, встановлюючи чіткі очікування і результати взаємодії з учнями. Вчителі, які не мають плану дій та не передбачають реакцій учнів, не тільки втрачають цінний навчальний час, але часто не отримують поваги від своїх учнів.

Учні як правило реагують позитивно на зміст навчального матеріалу, коли вчитель сповнений ентузіазму і захоплений освітнім процесом.

Вчителі повинен входити в свій клас кожен день 3 позитивним настроєм. Кожна людина проходить через особисті випробування, з якими буває важко впоратися. Не зважаючи на те, що у всіх бувають жахливі дні, включаючи й вчителів. Важливо, щоб особисті проблеми вчителя не заважали його здатності до навчання.

Не слід забувати, що при роботі з дітьми необхідно частіше ніж 3 дорослими створювати моменти психологічної релаксації. Для цього вчитель повинен включати гумор в свої щоденні уроки. Це може бути історія як пов'язана зі змістом навчального матеріалу так й відсторонений матеріал 3 досвіду вчителя, інших учнів тощо. Учням сподобається приходити в ваш клас, тому що вони люблять сміятися і дізнаватись про щось нове.

Навчання повинно бути захоплюючим. Ніхто не хоче проводити час в класі, де лекції і конспектування є нормою. Учням подобаються практичні заходи, де можна виконувати певні навчальні дії, де вони можуть вчитися активно. Учні 3 ентузіазмом ставляться до активних і наочним уроків, заснованим на застосуванні різних технологій.

У кожного учня є пристрасть до чогось. Вчитель повинен використовувати ці інтереси i пристрасті в своїх інтересах, включаючи їх в свої уроки. Опитування учнів $є$ гарним способом вимірювання цих інтересів. Як тільки вчитель дізнаєтеся, що цікавить його клас, він повинен знайти творчі способи інтегрувати цей інтерес у свої уроки. Гарний учитель використовує інтереси учнів в активізації освітнього процесу. 
Необхідно вводити різноманітні історичні довідки у зміст уроку. Це підтверджує актуальність матеріалу для життя людини, загострює процес запам'ятовування, а також це позбавляє учнів від монотонності заучування фактів.

Слід пам'ятати, що учні живуть не лише у межах вашого класу й виконання домашнього завдання не єдина їх мета діяльності поза школою. Учителю необхідно розмовляти з учнями про їхні інтереси і позакласні заходах, в яких вони беруть участь. Цікавтеся їхніми інтересами, навіть якщо ви не поділяєте їхню пристрасть. Подумайте про позакласні заходи, що відбуваються в цей конкретний день, і постарайтеся не перевантажувати своїх учнів.

Учні ніколи не будуть поважати вчителя, якщо він їх не поважаєте. Учитель ніколи не повинен кричати, використовувати сарказм, виділяти учнів з негативного боку або намагатися принизити їх. Це призведе до втрати поваги з боку всього класу.

Деякі учні потребують такого вчителя, який витратить більше часу ніж це передбачено програмою для засвоєння навчального матеріалу. Тому, вчителі надають можливість учням на додаткове навчання у вільний час від занять.

\section{Висновки}

Психолого-педагогічні компоненти, що впливають на побудову професійної кар'єри вчителя визначаються: рівнем мотивації професійної діяльності; здатністю до емпатії; рівнем агресивності; рівнем нервово-психічної стійкості; рівнем емоційного вигорання; сформованістю моральних, філософських, естетичних цінностей; психолого-педагогічною майстерністю; професійною та загальною ерудицією; культурою поведінки; колом інтересів; стилем спілкування; дотриманням прав та обов'язків тощо.

Перспективи подальших досліджень полягають у обгрунтуванні критеріїв та показників оцінювання психологопедагогічних компонентів побудови професійної кар'єри вчителя. 


\section{Література}

1. Алексенцева-Тімченко К.С. Соціальні умови формування успішної кар'єри : дис. ... канд. соціол. наук : 22.00.04 / Одеський нац. ун-т ім. I.I. Мечникова. Ін-т соціальних наук. Одеса, 2007. $181 \mathrm{c}$.

2. Альшевська Н.Ю. Трудова кар' єрапрацівників банківської системи в період ринкових перетворень : дис. ... канд. соціол. наук : 22.00.04 / НАН України; Ін-т соціології. Київ, 2000. 223 с.

3. Біла-Тіунова Л.Р. Службова кар'єра державного службовця: теорія та правове регулювання : дис. ... д-ра юрид. наук : 12.00.07 / Нац. ун-т «Одеська юрид. акад.». Одеса, 2012. 390 с.

4. Візіров Б.Й. Кар'єра державного службовця в Україні: теоретичні засади : дис. ... канд. наук з держ. управління : 25.00.03 / Нац. ун-т біоресурсів і природокористування України. Київ, 2009. 242 с.

5. Вінтоняк В.Ф. Професійний «Я-образ» як чинник визначення офіцером стратегії кар'єрного зростання : дис. ... канд. психол. наук : 19.00.10 / Київ. нац. торг.-екон. ун-т. Київ, 2014. 200 с.

6. Гейлик А.В. Організаційно-педагогічні умови професійного зростання майбутніх фахівців з економіки і підприємництва у процесі навчально-практичної діяльності : дис. ... канд. пед. наук : 13.00.04 / Нац. акад. пед. наук України, Ін-т вищ. освіти. Київ, 2013. 200 с.

7. Журавель А.В. Інтервізія як засіб підготовки майбутніх психологів до побудови професійної кар'єри : дис. ... канд. психол. наук : 19.00.10 / Київ. нац. торг. екон. ун-т. Київ, 2014. 200 с.

8. Канівець Т.М. Формування психологічної готовності студентів до здійснення майбутньої професійної кар'єри : дис. ... канд. психол. наук : 19.00.10 / Нац. акад. пед. наук України, Ін-т психології ім. Г.С. Костюка. Київ, 2013. 200 с.

9. Кримська О.М. Правові засади та форми забезпечення професійного зростання працівника в нових умовах економічного розвитку : дис. ... канд. юрид. наук : 12.00.05 / Східноукр. нац. ун-т ім. Володимира Даля. Луганськ, 2012. 200 с. 
10. Литвинюк Л.В.Педагогічне стимулювання професійного зростання вчителів загальноосвітніх навчальних закладів : дис... канд. пед. наук : 13.00.04 / Кіровоград. держ. пед. ун-т ім. В. Винниченка. Кіровоград, 2007. 255 с.

11. Мешко Г.М. Вступ до педагогічної професії : навч. посіб. Київ : Академвидав, 2010. 200 с.

12. Оксамитна С.М. Структурні та особистнісні передумови здійснення трудової кар'єри : дис. ... канд. соціол. наук : 22.00 .04 / НАН України. Київ, 1995. 215 с.

13. Поляков А.О. Педагогічні умови мотивації професійного зростання студентів педагогічних університетів у процесі неперервної освіти : дис. ... канд. пед. наук : 13.00.04 / Харків. нац. пед. ун-т ім. Г.С. Сковороди. Харків, 2008. 278 с.

14. Пригодій М.А. Сучасні аспекти підготовки вчителів технологій : монографія. Чернігів : ЧНПУ імені Т.Г. Шевченка, 2011. 384.

15. Стародубцев А.А. Службова кар'єра в органах внутрішніх справ України: адміністративно-правові засади : дис. ... д-ра юрид. наук : 12.00.07 / Харк. нац. ун-т внутр. справ. Харків, 2012. 235 с.

16. Ханенко I.І. Соціально-психологічні особливості професійного зростання жінок-керівників у правоохоронних органах України : дис. ... канд. психол. наук : 19.00.05 / Східноукр. нац. ун-т ім. Володимира Даля. Луганськ, 2012. 200 с.

17. Шеленкова Н.Л. Розвиток у майбутніх психологів психологічної готовності до здійснення професійної кар'єри : дис. ... канд. психол. наук : 19.00.10 / ВНЗ «УН-т економіки та права «Крок». Київ, 2014. 200 с.

18. Meador D. Strategies for Teachers to Develop Positive Relationships with Students. URL: https:/www.thoughtco.com/ develop-positive-relationships-with-students-3194339 (Дата звернення: 19.08.2019). 


\section{Олефіренко Т.О.}

\section{Психолого-педагогічний аналіз феномену професійної кар'сри вчителя}

\section{Анотація}

У статті доведено, що знання психолого-педагогічних основ феномену професійної кар'єри дозволяє врахувати висхідні і низхідні фази розвитку, критичні періоди життя, а також спрогнозувати вплив соціально-економічних та особистісних факторів на розвиток особистості вчителя. Обгрунтована необхідність врахування особливостей трудової діяльності сучасного вчителя, що обумовлюється специфікою середовища, наявністю постійних контактів 3 людьми, які мають різноманітні темпераменти, необхідністю витримувати емоційну стійкість. Підтверджена наявність ряду проблем, пов'язаних як із професійним розвитком особистості вчителя, так і з управлінням його кар'єрою. Такий стан речей обумовлений відсутністю цілеспрямованого впливу на процес формування та розвитку професійної кар'єри вчителів, а це у свою чергу призводить до зниження ефективності використання ресурсів закладу освіти. Актуальним залишається врахування основних завдань, які виконує вчитель у межах освітнього процесу (забезпечити читку структуру освітнього процесу; навчати 3 ентузіазмом і пристрастю; мати позитивний настрій; використовувати гумор під час проведення занять; підвищити зацікавленість навчанням учнів; використовувати інтереси учнів при проведенні занять; проявляти інтерес до життя учнів за межами закладу освіти; ставитися до учнів 3 повагою). При побудові професійної кар'єри вчителя доведена необхідність врахування психолого-педагогічних компонентів (рівень мотивації професійної діяльності; здатність до емпатії; рівень агресивності; рівень нервово-психічної стійкості; рівень емоційного вигорання; сформованість моральних, філософських, естетичних цінностей; психолого-педагогічна майстерність; професійна та загальна 
ерудиція; культура поведінки; коло інтересів; стиль спілкування; дотримання прав та обов'язків тощо).

Ключові слова: кар'єра вчителя, професійна кар'єра, психологічна підготовка, педагогічна підготовка, студент.

\section{Олефиренко Т.А.}

\section{Психолого-педагогический анализ феномена профессиональ- ной карьеры учителя}

\section{Аннотация}

В статье доказано, что знания психолого-педагогических основ феномена профессиональной карьеры позволяет учесть восходящие и нисходящие фазы развития, критические периоды жизни, а также спрогнозировать влияние социально-экономических и личностных факторов на развитие личности учителя. Обоснована необходимость учета особенностей трудовой деятельности современного учителя, что объясняется спецификой среды, наличием постоянных контактов с людьми, которые имеют различные темпераменты, необходимостью выдерживать эмоциональную устойчивость. Подтверждено наличие ряда проблем, связанных как с профессиональным развитием личности учителя, так и с управлением его карьерой. Такое положение вещей обусловлено отсутствием целенаправленного воздействия на процесс формирования и развития профессиональной карьеры учителей, а это в свою очередь приводит к снижению эффективности использования ресурсов учебного заведения. Актуальным остается учета основных задач, которые выполняет учитель в пределах образовательного процесса (обеспечить читка структуру образовательного процесса; учить с энтузиазмом и страстью; иметь позитивный настрой, использовать юмор во время проведения занятий; повысить заинтересованность знаний учащихся, использовать интересы учащихся при проведении занятий; проявлять интерес к жизни учащихся за пределами 
учебного заведения; относиться к ученикам с уважением). При построении профессиональной карьеры учителя доказана необходимость учета психолого-педагогических компонентов (уровень мотивации профессиональной деятельности, способность к эмпатии, уровень агрессивности, уровень нервно-психической устойчивости, уровень эмоционального выгорания; сформированность нравственных, философских, эстетических ценностей; психологопедагогическое мастерство; профессиональная и общая эрудиция; культура поведения; круг интересов, стиль общения, соблюдение прав и обязанностей и т.д.).

Ключевые слова: карьера учителя, профессиональная карьеpa, психологическая подготовка, педагогическая подготовка, студент. 